\title{
Performance of rapeseed and mustard (Brassica sp.) varieties/lines in north-east region (sylhet) of Bangladesh
}

\begin{abstract}
An experiment of rapeseed-mustard was conducted at the Agronomy Research field of Sylhet Agricultural University, Sylhet, during the Rabi season to identify the suitable short durable variety for utilizing the fallow land of Sylhet region that remain fallow after harvest of T. Aman rice. Eight varieties (Improved Tori, TS-72, BARI Sarisha-8, BARI Sarisha-9, BARI Sarisha-12, BARI Sarisha-14, BARI Sarisha-15, and Binasarisha-4) and four promising lines (BC-05115 Y, BC-05117 Y, BC-05118 $\mathrm{Y}$ and Nap-205) of rapeseed-mustard were evaluated. Results indicated that, growth as well as yield and yield attributes of rapeseed mustard were significantly differed. The variety Improved Tori, BARI Sharisa-8, BARI Sharisa-14 and BARI Sharisa-15 produced the highest seed yield and took minimum days to mature and their growth parameters were also highly significant and positive correlation was observed in seed yield with siliqua/plant, straw yield, biological yield, 1000 seed weight and harvest index. So, Improved Tori, BARI Sarisha-8, BARI Sarisha-14 and BARI Sarisha-15 are suitable for cultivation in north-east region (Sylhet) of Bangladesh.
\end{abstract}

Volume 5 Issue I - 2016

\author{
Mostofa Uddin Helal Md,' Nazrul Islam \\ Md,' Monjurul Kadir, ${ }^{2}$ Noor Hossain Miah' \\ 'Department of Agronomy, Sylhet Agricultural University, \\ Bangladesh \\ ${ }^{2}$ Plant Breeding Division, Regional Agricultural Research Station, \\ Bangladesh
}

\begin{abstract}
Correspondence: Md Nazrul Islam, Chairman, Department of Agronomy, Haor Agriculture, Sylhet Agricultural University, Sylhet, Bangladesh, Tel +880- I 7I-644-339-I,

Email nkakoli2003@yahoo.co.uk
\end{abstract}

Received: June 02, 2016 | Published: November 09, 2016

Keywords: rapeseed-mustard, varieties, lines, growth, yield, correlation

\section{Introduction}

Rapeseed-mustard belongs to the family of Cruciferae under genus Brassica are most important oilseed crops, source of vegetable oil, widely grown oilseed crops of Bangladesh occupying 0.532million ha of land and the production was 0.596 million MT (metric ton) with the yield of 1.12 MT (metric ton)/ha in 2013-14. ${ }^{1}$ It is now ranked first among oilseed crops in Bangladesh as well as the second largest oilseed crop in the world after soybean. ${ }^{2}$ Domestic production of edible oil in Bangladesh mainly comes from mustard and sesame. Bangladesh has been facing acute shortage of edible oil for the last several decades. Our internal production can meet only about $21 \%$ of our consumption. The rest $79 \%$ is met from the import. ${ }^{3}$ The country has to import more or less 1.9 million tons of edible oil and on average 31,685 MT mustard seeds for oil production from 2006 to 2010 annually. ${ }^{4}$ Mustard oil is used as cooking oil in the country. Increased oilseed production is needed not only to meet the demand of the increased population but also to reduce import of edible oil to save foreign currencies. Major mustard growing major districts of Bangladesh are Comilla, Tangail, Jessore, Sirajgong, Sylhet, Faridpur, Pabna, Faridpur, Madaripur, Jamalpur, Rajshahi, Dinajpur, Kushtia, Kishoregonj, Rangpur and Dhaka. ${ }^{5}$ Sylhet is situated in the Northeast part of Bangladesh, comparatively high rainfall area. The major cropping patterns in Sylhet are Fallow-Fallow-Boro rice $(17 \%)$, Fallow-T. Aman-Fallow (20\%), Boro rice-Fallow-T. Aman rice $(20 \%)$, Fallow-Aus rice-T. Aman rice $(20 \%)$ and a vast area about 2 , 28,980 ha remain fallow after harvest T. Aman rice in Rabi season. ${ }^{6}$ Cultivation of mustard could be possible if residual moisture remains in the field after harvest of T. Aman rice. It was reported that, some farmers of Sylhet region usually cultivate the local variety of Tori-7 which is low yielding and pest susceptible. Recently some improved; short duration high yielding varieties viz., Improved Tori, BARI Sarisha-14, BARI Sarisha-15 and Binasarisha-4 etc. were developed by research organizations. These varieties may replace the existing local Tori-7 in Sylhet and ultimately increase oil seed production to some extent in the country. So, the present study was undertaken to evaluate the performance of rapeseed-mustard varieties/lines to find out the short duration, high yielding variety which can be grown after harvest of T. Aman rice which remain fallow in Sylhet.

\section{Materials and methods}

The experiment was conducted at the Agronomy research field of Sylhet Agricultural University, under the Agro-Ecological Zone of Eastern Surma-Kushiyara Floodplain (AEZ 20) during Rabi season of (November, 2012 to February, 2013). The experimental field situated at $24^{\circ} 54^{\prime} 33.2^{\prime \prime} \mathrm{N}$ latitude and $91^{\circ} 54^{\prime} 7.15^{\prime \prime} \mathrm{E}$ longitude at the elevation of $30 \mathrm{~m}$ above the sea level. The soil belongs to the "Khadimnagar" soil series sandy loam in texture having moderate organic matter content (1.45\%), N $0.80 \%, \mathrm{~K} 0.07 \mathrm{~m} \mathrm{~mol} / 100 \mathrm{~g}$ of soil, $\mathrm{P}$ was $25 \mu \mathrm{g} / \mathrm{g}$ of soil and $\mathrm{S}$ was $10 \mu \mathrm{g} / \mathrm{g}$ of soil with $\mathrm{pH}$ value 5.2.

The experiment was laid out in a RCB (Randomized Complete Block) design with three replications. Eight varieties namely Improved Tori, TS-72, BARI Sarisha-8, BARI Sarisha-9, BARI Sarisha-12, BARI Sarisha-14, BARI Sarisha-15, and Binasarisha-4 and four advanced lines BC-05115 Y, BC-05117 Y, BC-05118 Y and Nap-205 of rapeseed-mustard were tested in this experiment. Seeds were collected from Bangladesh Agricultural Research Institute ${ }^{7}$ and Bangladesh Institute of Nuclear Agriculture (BINA). The experimental plots were fertilized at the rate of $128.8,36,45,28.8,2.21,1.38 \mathrm{~kg} \mathrm{~N}$, $\mathrm{P}, \mathrm{K}, \mathrm{S}, \mathrm{B}$ and $\mathrm{Zn} / \mathrm{ha}$ respectively. During final land preparation, half of the urea and total amount of all other fertilizers were applied and incorporated into soil and rest of the urea was top dressed at 24days after sowing (DAS). Sowing was done on November 27, 2012. Seeds were sown in line with spacing of $25 \mathrm{~cm} \times 5 \mathrm{~cm}$ and the area of each unit plot was $10 \mathrm{~m}^{2}(4 \mathrm{~m} \times 2.5 \mathrm{~m})$. Two hand weeding were done at $14-15$ DAS and 24-25 DAS manually. Light irrigations were given one at 20 
DAS and another at 40 DAS. The crop was sprayed with Malathion 57 EC to control aphids at siliquae formation stage.

The growth parameters like plant height, number of branches/ plant, number of leaves/plant, and dry matter production/plant were taken at 20 DAS interval until harvest by destructive sampling method using 10plants for every sampling time from each plot and harvested during February 10 to 24, 2013 depending on the maturity of variety. At maturity stage i.e. when $80 \%$ of the pod turned chocolate brown to black in colour, the crop was harvested from the center of each plot in $3 \mathrm{~m} \times 3 \mathrm{~m}$ area at ground level for seed yield. Prior to harvesting, ten plants were randomly uprooted for yield attributes viz., number of siliqua/plant, number of seeds/siliquae, weight of 1000-seeds. Seeds from harvested area collected and sun dried in the floor for 3-4 days to obtain proper seed moisture content of $12 \%$ to get optimum seed weight. The straw was also dried in the sun; both seed and straw yields were recorded. Data were analyzed by computer package program MSTAT C and mean differences were adjudged by the least significant difference (LSD) test at 5\% level of significance. The correlation coefficients were calculated between the seed yield with yield and yield attributes as well as dry mater production/plant at different days after sowing (DAS) according to Al Jibouri et al. ${ }^{8}$ The significance of correlation coefficients was tested against ' $r$ ' values given by Fisher et al. ${ }^{9}$

\section{Results and discussion}

\section{Growth characteristics of different rapeseed-mustard}

Plant height (cm): The plant height was significantly different among the varieties at all growing stages (Figure 1). At 20 DAS, the highest plant height was recorded in Binasarisha-4 and the lowest in BC-05117 Y. After 40 DAS, it increased sharply up to 60 DAS where maximum plant height was recorded in BARI Sarisha-15 $(119.8 \mathrm{~cm})$ which was at par with all the varieties except BARI Sarisha-14. At harvest, the variety BARI Sarisha-15 produced the tallest plant $(122.0 \mathrm{~cm})$ and it was identical with BARI Sarisha-8 $(117.5 \mathrm{~cm})$ and line BC-05118 Y $(109.4 \mathrm{~cm})$. It was supported by BARI, 2010 and produced $105.8 \mathrm{~cm}$ and $113.6 \mathrm{~cm}$ tallest plant in BARI Sarisha-8 and BARI Sarisha-15 respectively. Whereas, BARI Sharisa-14 produced the shortest plant $(83.6 \mathrm{~cm})$ which was supported by Ali et al., ${ }^{10}$ Bhuiyan ${ }^{11}$ and Alam, ${ }^{12}$ Sana et al., ${ }^{13}$ reported that, the final plant height reflected the growth behavior of a crop.

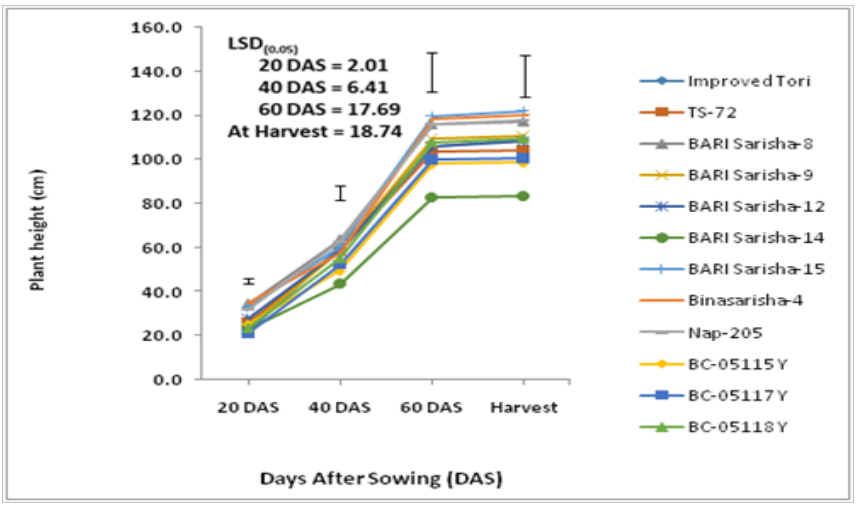

Figure I Plant height at different days after sowing (DAS) of rapeseedmustard varieties/lines.
Number of leaves/plant: Number of leaves/plant at different days after sowing did not differ significantly up to 40 DAS but later on showed significant variation at 60 DAS and at harvest (Figure 2). The maximum number of leaves/plant (29.0) was produced by the variety BARI Sarisha- 15 and the minimum by the line Nap-205 (8.87) at 60 DAS. The number of leaves/plant showed declining trend after 60 DAS among all the varieties. A good number of leaves (20.60) remain at harvest in BARI Sarisha-15 that constitute higher leaf area index and enhanced photosynthetic activity of plants which eventually contribute to higher yield. The minimum number of leaves/plant in line Nap-205 (6.50) might be due to genetic makeup of these varieties/ lines.

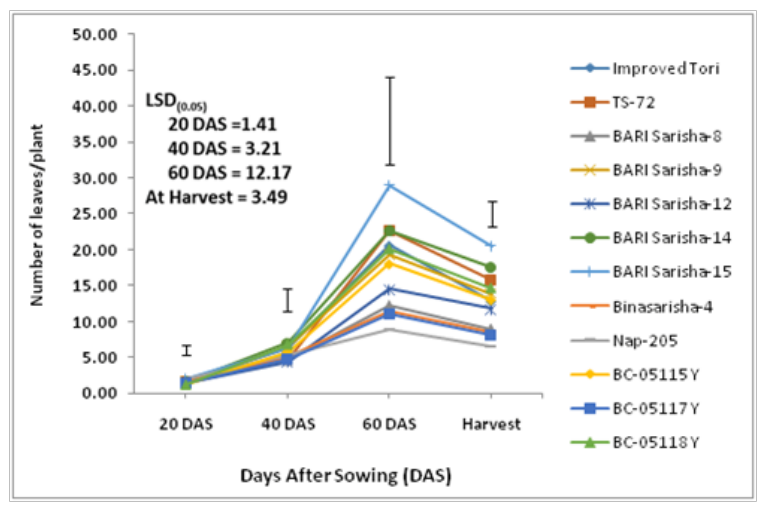

Figure 2 Number of leaves/plant at different days after sowing (DAS) of rapeseed-mustard varieties/lines.

Number of branches/plant: Significant variation observed in number of branches/plant from 40 DAS and onwards (Figure 3). At 40 DAS, Improved Tori produced the maximum number (2.0) of branches/plant and continued until harvest (9.57) and it was identical with BARI Sarisha-8, BARI Sarisha- 15 which supported by BARI ${ }^{7}$ and Mamun et al..$^{14}$ and they showed that, BARI Sarisha-15 produced 7.45 branches/plant. Whereas, minimum branches/plant produced by the line BC-05117 Y at 60 DAS until harvest. Sana et al., ${ }^{13}$ reported that, higher number of branches/plant is the result of genetic makeup of the crop and environmental conditions which play a remarkable role towards the final seed yield of the crop. The yield contributing character like number of branches/plant is an important trait which helps to produce more leaves and pods and ultimately assist in photosynthesis which reflects the present study.

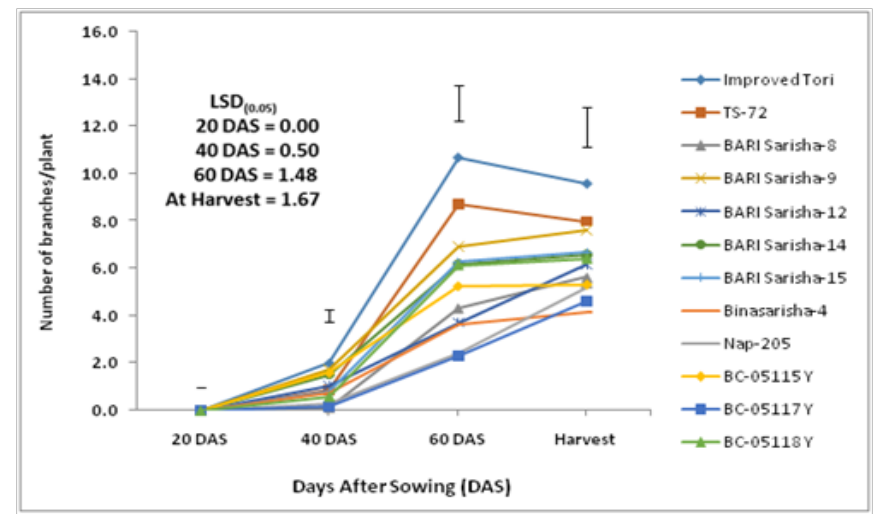

Figure 3 Number of branches/plant at different days after sowing (DAS) of rapeseed-mustard varieties/lines. 
Dry matter/plant: Significant variations were observed in dry matter production at different days after sowing (Figure 4). The highest dry matter weight (1.19g/plant) was observed in BARI Sarisha- 8 and the lowest in BARI Sarisha-12 at 20 DAS, but 40 DAS, the highest dry matter $(34.33 \mathrm{~g} / \mathrm{plant})$ was found in BARI Sarisha-9 and the lowest $(13.47 \mathrm{~g} /$ plant) by Nap-205. On the other hand at 60 DAS, the highest dry matter $(79.69 \mathrm{~g} /$ plant $)$ was obtained from Binasarisha-4 while the line BC-05117 Y produced the lowest dry matter (20.44g/plant). At harvest, dry matter of BARI Sarisha-8 was the highest $(309.21 \mathrm{~g}$ / plant) and the lowest (163.93g/plant) from variety BARI Sarisha-14. Dry matter production pattern at different days after sowing showed that different varieties varied their dry matter production pattern. These variations were noticed from one stage to another stage and none of the variety/line followed the same pattern at different days of sampling. It indicated that each variety/line responded independently from one stage to another stage to the environment in respect of growth of plant, branching and leaf number and ultimately differed in dry matter production.

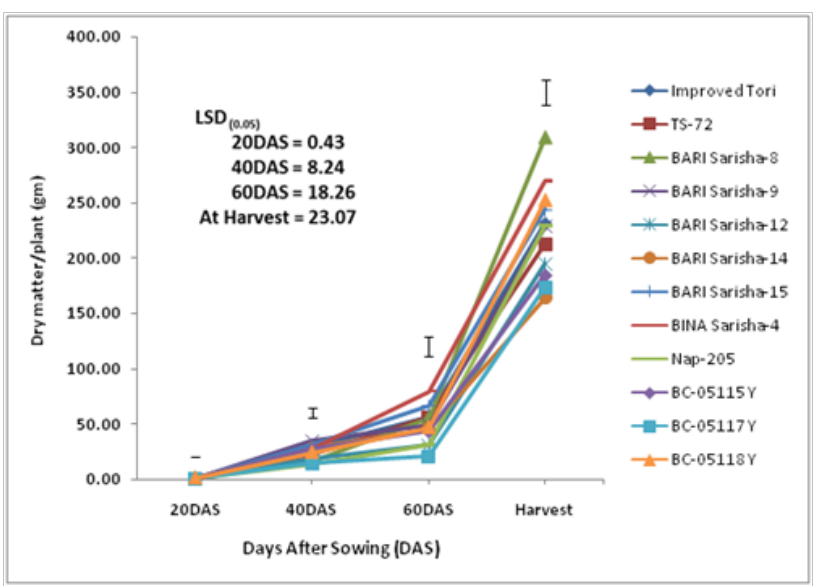

Figure 4 Dry matter/plant (gm) at different days after sowing (DAS) of rapeseed-mustard varieties/lines.

Crop duration (days): The crop duration of rapeseed and mustard significantly differed among the varieties (Table 1). All the varieties took less than 80 days to mature except Binasharisa-4 which took maximum days (85). The variety Improved Tori (71) and BARI Sharisa-14 (72) took minimum days to mature. The variety TS-72, BARI Sharisa-9, BARI Sharisa-15 and line BC 05115 Y also took minimum days (74-75) to mature. Though BARI Sharisa-15 took 75 days to mature but it gives higher yield than Improved Tori (71) and BARI Sharisa-14 (72) but other varieties except BARI Sharisa-8 which needs higher days to mature (77). Crop duration is an inevitable part of Brassica oilseed crop in aspect of Bangladesh. Generally short duration varieties are more preferable to the farmers of Bangladesh as these can be fitted in rice based cropping pattern. ${ }^{6}$ Those varieties took less than 80 days to mature, may be well fitted into the "T. Aman rice-Mustard-Boro rice" cropping pattern. Considering overall yield and crop duration, BARI Sharisa-15 may be suited best for fallow land in Sylhet.

\section{Yield and yield attributes of rapeseed mustard}

Plant population $/ \mathrm{m}^{2}$ : Plant population $/ \mathrm{m}^{2}$ there was no significant variation observed among all of the varieties/lines at harvest (Table 1). The maximum plant population found in the line BC-05118 Y (56.83/ $\left.\mathrm{m}^{2}\right)$ and it was followed by the variety BARI sarisha-15 $\left(53.67 / \mathrm{m}^{2}\right)$ and the lowest plant population was recorded in the variety BARI sarisha-14 $\left(46.67 / \mathrm{m}^{2}\right)$. Generally, the $50-60$ plants $/ \mathrm{m}^{2}$ produced a good seed yield in Bangladesh condition (BARI, 2010).

Siliqua/plant: Significant variation was found in the number of siliqua/plant among the varieties (Table 1). The maximum number of siliqua/plant was produced by the variety Improved Tori (120.27) and it was statistically similar with BARI sarisha-8, BARI sarisha-9, BARI sarisha-14 and BARI sarisha-15. Similar results were observed by Mondal et al. ${ }^{15}$ and Alam. ${ }^{12}$ They were found maximum number of siliqua/plant (136) in the variety J-5004 which was identical with the variety Improved tori. On the other hand, Mamun et al., ${ }^{14}$ reported that, BARI Sharisa-15 produced maximum (73.11) siliqua/ plant under 40 plants $/ \mathrm{m}^{2}$. Yadav et al., ${ }^{16}$ suggested that for ensuring high yields in $B$. juncea, the plant type should have more number of siliqua/plant (100-125). Other varieties like TS-72 (97.60), BARI Sarisha-12 (95.07), Binasarisha-4 (89.43) and line Nap-205 (92.17) had intermediary siliqua/plant. On the contrary, two advanced lines (BC-05115 Y and BC-05117 Y) produced similar and lowest no. of silique/plant (46-49).

Seeds/siliquae: Significant variations were observed in terms of number of seeds/siliqua among all the varieties (Table 2). The maximum number of seeds/siliquae (36.27) was produced by the line BC-05118 Y and it was statistically identical to the line BC-05117 Y (31.23), BARI sarisha-14(34.30) and BARI sarisha-8(32.37). The minimum number of seeds/siliqua was produced by the variety BARI sarisha-12(16.77) and it was similar to the variety Improved tori(19.43), TS-72 (17.20) and BARI sarisha-9(18.20) statistically. Jahan et al., ${ }^{17}$ found that the lowest number of seeds/siliquae was in Improved Tori(18.0).

1000 seed weight (g): In case of 1000 seed weight significant variations were observed among all the varieties (Table 1). Identically, the highest 1000 seed weight $(4.00 \mathrm{~g})$ was recorded in the variety Binasarisha-4 while moderate seed weight found in BARI Sarisha-14 $\left(3.67 \mathrm{~g}\right.$ ) and BARI Sarisha-15 (3.63g) (Table 1). Mamun et al., ${ }^{14}$ observed that, 1000 seeds weight was $3.20 \mathrm{~g}$ in BARI Sarisha-15 when 10 plant population $/ \mathrm{m} 2$. The lowest 1000 seed weight $(2.90 \mathrm{~g})$ was recorded from the variety Improved Tori which was similar to variety TS-72 $(2.97 \mathrm{~g})$ and line $\mathrm{BC}-05115 \mathrm{Y}(2.90 \mathrm{~g})$ and $\mathrm{BC}-05118 \mathrm{Y}$ $(2.93 \mathrm{~g})$. Mondal et al, ${ }^{18}$ described that, weight of 1000 seeds varied from variety to variety and species to species. They found thousand seed weight $2.50-2.65 \mathrm{~g}$ in case of Improved Tori (B. campestris)

Seed yield (t/ha): Production of higher yield by different varieties might be due to the contribution of cumulative favorable effects of the crop characteristics viz., number of branches/plant, siliquae/plant and seeds/siliqua. The seed yield of rapeseed/mustard varieties/lines differed significantly (Table 1 ). The variety BARI Sarisha- 8 produced the maximum seed yield (1.46t/ha) due to maximum number of branches/plant, siliqua/plant, seeds/siliquae and it was statistically similar with BARI Sarisha-15 (1.29t/ha), BARI Sarisha-14 (1.20t/ ha) and Binasarisha-4 (1.19t/ha). Mamun et al., ${ }^{14}$ reported that, BARI Sarisha-15 gives higher yield (1.07t/ha) under 100 plants $/ \mathrm{m}^{2}$. Oilseed Research Centre of Bangladesh Agricultural Research Institute (BARI) conducted an experiment with 16 varieties/lines of rapeseed and observed that BARI sharisa- 8 produced maximum seed yield. ${ }^{19}$ On the other hand, lowest seed yield $(0.72 \mathrm{t} / \mathrm{ha})$ was obtained from the line BC-05115 Y followed by other two lines BC-05117 Y and BC- 
05118 Y. The variety Binasarisha-4 showed reasonable seed yield but took maximum days to mature. Straw yield followed the similar trend as mentioned in seed yields.

Biomass yield (t/ha): In case of Biomass yield, there was significant variations observed (Table 1). The maximum biomass yield (5.91t/ha) was obtained by the variety BARI Sarisha- 8 which was statistically identical with Binasarisha-4, BARI Sarisha-15, Improved Tori and the minimum (3.18t/ha) by the line BC-05115 Y followed by BC05117 Y, TS-72 and BARI Sarisha-12 (Table 1). Mamun et al., ${ }^{15}$ stated that, BARI Sarisha-15 gives higher biomass yield (3.00t/ha) under 40 plants $/ \mathrm{m}^{2}$. Bhargava ${ }^{20}$ demonstrated that biological yield was positively correlated with higher grain yield of rapeseed-mustard. The higher biological yield might be attributed for their tall plants and more branching habits.

Harvest index (\%): There was no significant variation in respect of harvest index among all the tested varieties and lines (Table 1). However, maximum $(27.73 \%)$ harvest index found in the variety BARI sarisha-14 and similar with BARI sarisha-15 (27.47\%) and the minimum $(23.57 \%)$ in the line BC-05118 Y. Mamun et al. ${ }^{15}$ stated that, In BARI Sarisha-15 harvest Index was $34.49 \%$ under 70 plants/ $\mathrm{m} 2$.

Relationship between seed yield and yield contributing characters of different rapeseed/mustard varieties/ lines

Relationship between seed yield and yield attributes of different mustard varieties/lines in Table 2. It appears that, seed yield was significantly and positively correlated with number of siliquael plant, 1000 seed weight, straw yield, plant height, biological yield and harvest index which implies that seed yield would increase with the increase of these yield attributes. It was also reported by Zehra et al. ${ }^{21}$ But it had positive non-significant correlation with number of branches/plant, number of leaves/plant, number of seeds/siliquae, crop duration and plant population.

Siliquae/plant showed highly significant and positive relationship with straw yield, plant height, biological yield, harvest index and significant but negative relationship with seeds/siliquae. Seeds/ siliquae had positive significant relationship with crop duration but non-significant association with 1000 seed weight, straw yield, plant height, biological yield and harvest index. Plant height had positive significant association with biological yield and crop duration but non-significant positive relation with plant population but negative with harvest index. Thousand seed weight had positive significant correlation with seed yield, straw yield, biological yield and crop duration but non-significant positive association with plant height and harvest index and negative with plant population. These attributes are important for future breeding program of mustard and it also indicated by Ana et al. ${ }^{22}$

\section{Correlation between seed yield and total dry matter}

A relationship between seed yield and total dry matter production at different DAS is presented in Table 3. Seed yield was positively and highly correlated with total dry matter (g/plant) at $60 \mathrm{DAS}$ and at harvest but positive and non-significant relationship with dry matter at 20 DAS and 40 DAS. Dry matter at 40 DAS had positive and highly correlated with dry matter at 60 DAS. Dry matter at 20 DAS was positive and highly correlated with dry matter at harvest but nonsignificant relationship with dry matter at 60 DAS and negative with 40 DAS.

Table I Plant population $/ \mathrm{m}^{2}$, Siliqua/plant, seeds/siliquae, 1000 seed weight, seed yield, straw yield, biomass yield, harvest index and crop duration of different rapeseed/mustard varieties/lines during Rabi season of 2012-13 in Sylhet

\begin{tabular}{|c|c|c|c|c|c|c|c|c|c|}
\hline Variety/line & $\begin{array}{l}\text { Plant } \\
\text { Population/ } \\
\text { M2 }\end{array}$ & $\begin{array}{l}\text { Number } \\
\text { of siliqua/ } \\
\text { plant }\end{array}$ & $\begin{array}{l}\text { Number } \\
\text { of seeds/ } \\
\text { siliquae }\end{array}$ & $\begin{array}{l}1000 \text { Seed } \\
\text { Weight (G) }\end{array}$ & $\begin{array}{l}\text { Seed } \\
\text { Yield (t/ } \\
\text { ha) }\end{array}$ & $\begin{array}{l}\text { Straw } \\
\text { Yield (t/ } \\
\text { ha) }\end{array}$ & $\begin{array}{l}\text { Biomass } \\
\text { Yield (t/ } \\
\text { ha) }\end{array}$ & $\begin{array}{l}\text { Harvest } \\
\text { Index } \\
(\%)\end{array}$ & $\begin{array}{l}\text { Crop } \\
\text { Duration } \\
\text { (days) }\end{array}$ \\
\hline Improved Tori & 52.83 & $120.27 \mathrm{a}$ & $19.43 q$ e & $2.90 \mathrm{e}$ & $1.16 \mathrm{a}-\mathrm{c}$ & $3.63 \mathrm{bc}$ & $4.79 \mathrm{bc}$ & 24.19 & $71 \mathrm{e}$ \\
\hline TS-72 & 51 & $97.60 \mathrm{bc}$ & $17.20 \mathrm{e}$ & $2.97 \mathrm{e}$ & 0.96 b-e & $2.98 b-d$ & $3.95 b-d$ & 24.4 & $74 d$ \\
\hline BARI Sarisha-8 & 48 & $104.70 \mathrm{ab}$ & $32.37 \mathrm{a}-\mathrm{c}$ & $3.50 \mathrm{bc}$ & $1.46 \mathrm{a}$ & $4.45 \mathrm{a}$ & $5.91 \mathrm{a}$ & 24.7 & $77 b$ \\
\hline BARI Sarisha-9 & 53.33 & $105.10 \mathrm{ab}$ & $18.20 \mathrm{e}$ & $3.07 \mathrm{de}$ & $1.09 \mathrm{~b}-\mathrm{d}$ & $3.34 \mathrm{bc}$ & $4.43 \mathrm{bc}$ & 24.31 & $74 d$ \\
\hline BARI Sarisha-12 & 51.33 & $95.07 \mathrm{bc}$ & $16.77 \mathrm{e}$ & $3.20 \mathrm{c}-\mathrm{e}$ & $0.95 \mathrm{c}-\mathrm{e}$ & $2.83 \mathrm{~cd}$ & $3.78 \mathrm{~cd}$ & 24.92 & $75 c$ \\
\hline BARI Sarisha-14 & 46.67 & 99.60 a-c & $34.30 a b$ & $3.67 b$ & $1.20 \mathrm{a}-\mathrm{c}$ & $3.12 b-d$ & $4.44 \mathrm{bc}$ & 27.77 & $72 \mathrm{e}$ \\
\hline BARI Sarisha-15 & 53.67 & $101.43 \mathrm{a}-\mathrm{c}$ & $30.40 \mathrm{~b}-\mathrm{d}$ & $3.63 b$ & $1.29 \mathrm{ab}$ & $3.41 b c$ & $4.71 b c$ & 27.47 & $75 c$ \\
\hline Binasarisha-4 & 49.33 & $89.43 \mathrm{bc}$ & $30.13 \mathrm{~b}-\mathrm{d}$ & $4.00 \mathrm{a}$ & $1.19 \mathrm{a}-\mathrm{c}$ & $3.80 \mathrm{ab}$ & $4.99 a b$ & 24.06 & $85 a$ \\
\hline Nap-205 & 50 & $92.17 \mathrm{bc}$ & $28.27 \mathrm{~cd}$ & $3.37 b-d$ & $1.13 b-d$ & $3.52 \mathrm{bc}$ & $4.65 \mathrm{bc}$ & 24.38 & $77 b$ \\
\hline BC-05115 Y & 47.33 & $49.00 \mathrm{~d}$ & $26.83 d$ & $2.90 \mathrm{e}$ & $0.72 \mathrm{e}$ & $2.46 \mathrm{~d}$ & $3.18 \mathrm{~d}$ & 22.82 & $75 c d$ \\
\hline BC-05117 Y & 50.5 & $46.27 d$ & 31.23 a-d & $3.07 \mathrm{de}$ & $0.80 \mathrm{de}$ & $2.44 \mathrm{~d}$ & $3.24 \mathrm{~d}$ & 24.95 & $76 b$ \\
\hline BC-05118 Y & 56.83 & $81.47 c$ & $36.27 \mathrm{a}$ & $2.93 \mathrm{e}$ & $1.14 \mathrm{a}-\mathrm{c}$ & $3.68 a b$ & $4.82 b c$ & 23.59 & $77 b$ \\
\hline \multirow[t]{2}{*}{$\operatorname{LSD}(0.05)$} & NS & $20.97^{* *}$ & $5.45^{* *}$ & $0.33^{* *}$ & $0.34 * *$ & $0.82 * *$ & $1.08 * *$ & NS & $0.84 * *$ \\
\hline & 17.28 & 14.03 & 12.28 & 6.09 & 18.76 & 14.98 & 14.8 & 9.71 & 0.67 \\
\hline
\end{tabular}

**Significant at $1 \%$ level of probability

NS = Not significant 
Table 2 Relationship between seed yield and yield contributing characters of different rapeseed/mustard varieties/lines

\begin{tabular}{|c|c|c|c|c|c|c|c|c|c|c|c|}
\hline \multirow{2}{*}{ Characters } & \multirow{2}{*}{$\begin{array}{l}\text { Leaves } \\
\text { Iplant }\end{array}$} & \multirow{2}{*}{$\begin{array}{l}\text { Siliquae } \\
\text { Iplant }\end{array}$} & \multirow{2}{*}{$\begin{array}{l}\text { seeds } \\
\text { /siliquae }\end{array}$} & \multirow{2}{*}{$\begin{array}{l}1000 \\
\text { seed } \\
\text { weight }\end{array}$} & \multirow{2}{*}{$\begin{array}{l}\text { Straw } \\
\text { Yield }\end{array}$} & \multirow{2}{*}{$\begin{array}{l}\text { Plant } \\
\text { Height }\end{array}$} & \multirow{2}{*}{\multicolumn{2}{|c|}{$\begin{array}{l}\text { Biological Harvest } \\
\text { yield index }\end{array}$}} & \multirow{2}{*}{$\begin{array}{l}\text { Crop } \\
\text { duration }\end{array}$} & \multirow{2}{*}{$\begin{array}{l}\text { Plant } \\
\text { population }\end{array}$} & \multirow{2}{*}{$\frac{\text { Seed }}{\text { Yield }}$} \\
\hline & & & & & & & & & & & \\
\hline $\begin{array}{l}\text { Branches/ } \\
\text { plant }\end{array}$ & $0.398 * *$ & $0.69 \mid * *$ & $-0.329 *$ & $-0.324 *$ & $0.142 \mathrm{NS}$ & $0.017 \mathrm{NS}$ & $0.178 \mathrm{NS}$ & $0.210 \mathrm{NS}$ & $0.52 I^{*}$ & 0.077 NS & $0.247 \mathrm{NS}$ \\
\hline Leaves/plant & & $0.175 \mathrm{NS}$ & $-0.035 \mathrm{NS}$ & $0.057 \mathrm{NS}$ & $0.137 \mathrm{NS}$ & $-0.045 \mathrm{NS}$ & $0.163 \mathrm{NS}$ & $0.155 \mathrm{NS}$ & $-0.314 \mathrm{NS}$ & $0.094 \mathrm{NS}$ & $0.208 \mathrm{NS}$ \\
\hline Siliquae/plant & & & $-0.323^{*}$ & $0.207 \mathrm{NS}$ & $0.439 * *$ & $0.326^{*}$ & $0.495 * *$ & $0.360 *$ & $-0.179 \mathrm{NS}$ & $0.129 \mathrm{NS}$ & $0.575^{* *}$ \\
\hline Seeds/siliquae & & & & $0.182 \mathrm{NS}$ & $0.144 \mathrm{NS}$ & $-0.067 \mathrm{NS}$ & $0.159 \mathrm{NS}$ & $0.123 \mathrm{NS}$ & $0.326 *$ & -0.102 NS & $0.18 \mathrm{NS}$ \\
\hline $\begin{array}{l}1000 \text { seed } \\
\text { weight }\end{array}$ & & & & & $0.352^{*}$ & $0.192 \mathrm{NS}$ & $0.375^{*}$ & $0.190 \mathrm{NS}$ & $0.526 *$ & $-0.105 \mathrm{NS}$ & $0.38 I *$ \\
\hline Straw yield & & & & & & $0.543 * *$ & $0.986 * *$ & $-0.068 \mathrm{NS}$ & $0.296 \mathrm{NS}$ & $0.324 *$ & $0.813 * *$ \\
\hline Plant height & & & & & & & $0.514 * *$ & $-0.167 \mathrm{NS}$ & $0.408^{*}$ & $0.309 \mathrm{NS}$ & $0.366^{*}$ \\
\hline $\begin{array}{l}\text { Biological } \\
\text { yield }\end{array}$ & & & & & & & & 0.096 NS & $0.264 \mathrm{NS}$ & $0.314 \mathrm{NS}$ & $0.898 * *$ \\
\hline Harvest index & & & & & & & & & $-0.156 \mathrm{NS}$ & $-0.07 I \mathrm{NS}$ & $0.520 * *$ \\
\hline Crop duration & & & & & & & & & & $0.008 \mathrm{NS}$ & $0.144 \mathrm{NS}$ \\
\hline $\begin{array}{l}\text { Plant } \\
\text { population }\end{array}$ & & & & & & & & & & & $0.244 \mathrm{NS}$ \\
\hline
\end{tabular}

**Significant at $1 \%$ level of probability

*Significant at $5 \%$ level of probability

NS, not significant.

Table 3 Correlation between seed yield and total dry matter (g/plant)

\begin{tabular}{lllll}
\hline Total dry matter $(\mathbf{t d m})$ & $\mathbf{4 0}$ das & $\mathbf{6 0}$ das & Harvest & Seed Yield \\
\hline 20 DAS & $-0.112 \mathrm{NS}$ & $0.171 \mathrm{NS}$ & $0.568^{* *}$ & $0.296 \mathrm{NS}$ \\
$\mathbf{4 0}$ DAS & & $0.472^{* *}$ & $0.014 \mathrm{NS}$ & $0.059 \mathrm{NS}$ \\
60 DAS & & & $0.578^{* *}$ & $0.441^{* *}$ \\
Harvest & & & $0.593^{* *}$
\end{tabular}

**Significant at $1 \%$ level of probability

NS, not significant.

\section{Conclusion}

Considering the growth parameters as well as yield and yield attributes indicated that, the variety BARI Sharisa- 8 produced the highest yield and at par with BARI Sharisa-14, BARI Sharisa-15, and Improved Tori. These varieties showed moderate seed size, higher number of siliqua/plant, and number of seeds/siliquae. Side by side growth parameters also showed that these varieties are dwarf and semi-dwarf in plant height with comparatively higher number of branches/plant, number of leaves/plant at late vegetative stage. On the other hand, correlation studies with seed yield verses yield attributing characters also indicating similar trend. So, these varieties could be suitable for north-east part of Bangladesh i.e. Sylhet aimed at higher yield with minimum crop duration and may be well fitted after harvesting of T. Aman rice into the "T. Aman rice-Mustard-Boro rice" cropping pattern.

\section{Acknowledgements}

None.

\section{Conflict of interest}

The author declares no conflict of interest.

\section{References}

1. Agricultural Information Service AIS. Krishi Diary (In Bangla). Agro for Ser Khamarbari, Farmgate, Dhaka, Bangladesh; 2015. 16 p.

2. FAO. Food and Agriculture Organization. FAOSTAT database of Agriculture (Crops). 2007.

3. Begum F, Hossain F, Mondal MRI. Influence of Sulphur on morphophysiological and yield parameters of rapeseed. Bangladsh Journal of Agril Res. 2012;37(4):645-652. 
4. Food and Agriculture Organization. FAOSTAT database of Agriculture (Crops). FAO; 2011.

5. BBS (Bangladesh Bureau of Statistics). Statistical Yearbook of Bangladesh, Statistics Division. Ministry of Planning, Govt People's Repub Bangladesh; 2010. p. 101-125.

6. BARC (Bangladesh Agricultural Research Council). Utilization of Fallow Land in Sylhet Region and Crop Production Plan. Farmgate, New Airport Road, Dhaka; 2011. 12 p.

7. Annual Report. Oilseed Research Centre. Gazipur: Bangladesh Agril Res Inst (BARI) Joydebpur; 2010.

8. A1-Jibouri HA, Miller PA, Robinson HF. Genotype and environmental variances and co-variance in upland cotton cross of interspecific origin. American Society of Agronomy. 1958;50(10):633-637.

9. Fisher RA, Yates F. Statistical tables for biological, Agriculture and medical research. Oliver and Boyd, Edinburgh. 3rd Ed. 1963. 112 p.

10. Ali MH, Zaman SMH, Hossain SMA. Variation in yield, oil and protein content of rapeseed (Brassica campestris) in relation to levels of nitrogen, sulphur and plant density. Indian J Agron. 1996;41(2):290-295.

11. Bhuiyan MR, Ed Huda, N Hussain. Techniques of multiplication of pulse and oilseeds. Pulse and oilseeds techniques of Bangladesh. BADC; 1989. p. 98-103.

12. Alam MM, Ferdousi Begum, Pryanka Roy. Effect of variety and row spacing on the yield and yield contributing characters of rapeseed and mustard. Genotypes grown under late sown condition. Bangladesh J Agril Res. 2014;39(2):311-336.

13. Sana M, Ali A, Malik MA, et al. Comparative yield potential and oil contents of different canola cultivars (Brassica napus L.). Pakistan J Agron. 2003;2(1):1-7.
14. Mamun F, Ali MH, Chowdhury IF, et al. Performance of rapeseed and mustard varieties grown under different plant density. Sci Agri. 2014;4(2):70-75.

15. Mondal MR, Islam MA, Khaleque MA. Effect of variety and planting date on the yield performance of mustard and rapeseed. Bangladesh J Agril Sci. 1992;19(92):181-188.

16. Yadav TP, Yadava AK, Singh A. A concept of plant ideotype in Indian mustard (Brassica juncea L.) 5th International rapeseed conference, Malmo, Sweden; 1978.

17. Jahan MH, Zakaria AKM. Growth and yield performances of different varieties of rapeseed, mustard and canola in level Barind Tract Progress. Agric. 1997;8(1\&2):144-152.

18. Mondal MRI, Wahab MA. Production Technology of Oilseeds. Oilseed Res Centre, Gazipur: Bangladesh Agril Res Inst Joydebpur; 2001. p. 6-24.

19. Anonymous. Adaptation trail of rapeseed mustard. Jamalpur: Annual Research Report of RARS; 2012. p. 27-29.

20. Bhargava SC. Physiology In: Oilseed Brassica in Indian Agriculture. Eds UL Chopra and Shyan Prakas, Har-Anand Publications and Vikas Pulish Pvt Ltd; 1991. p. 161-197.

21. Zehra A, Gulcan K. Genetic variability and association studies of some quantitative characters in winter rapeseed (Brassicanapus L). African $J$ Biotec. 2009; 8(15):3547-3554.

22. Ana MJ, Radovan M, Anto M, et al. Correlation and path analysis of quantitative traits in winter rapeseed (B. napus L.). Agric Conspec Sci. 2008;73(1):13-18. 